ANNA SÁDOVSKÁ

Faculty of Education

Trnava University

Trnava (Slovakia)

ORCID ID: http://orcid.org/oooo-ooo3-3309-4819

\section{PETER KUSÝ}

Faculty of Education

Trnava University

Trnava (Slovakia)

ORCID ID: http://orcid.org/oooo-0oo3-2804-0605
Forum Pedagogiczne $2018 / 2$

Wpłynęło: 31.03.2018 Zatwierdzono do druku: 26.09.2018 DOI: 10.21697/fp.2018.2.14

\title{
PUPILS' PROSOCIALITY AND ITS RELATIONS TO THEIR MEANING OF LIFE AND TEACHER'S INTERACTION STYLE
}

\begin{abstract}
The study deals with pupils' self-perceived prosocial behaviour and its correlations to pupils' meaning of life and teacher's interaction style. The pupils (14-and-15-years old) from lower secondary school were respondents of this research. The objective was to find out what relation exists between self-perceived prosocial behaviour and teacher 's interaction style. At the same time, we analysed the relation between pupils' self-perceived behaviour and pupils' meaning of life. It was shown that a teacher may improve self-perceived prosocial behaviour of pupils if s/he is evaluated with a higher score in the areas such as leadership, understanding and responsibility. On the contrary, if a teacher's interaction style is strict, uncertain, dissatisfied and admonishing, it correlates negatively with selfperceived prosocial behaviour of pupils.
\end{abstract}

Keywords: teacher's interaction style, meaning in life, prosocial behaviour.

\section{Introduction}

As some current researches have affirmed the important role of prosociality in terms of meaning in life, we decided to find some evidence of it via correlating results of self-perceived prosocial behaviour and meaning in life in a group of 14-and-15-year old pupils. The relations of self-reported prosocial behaviour to meaning in life have been shown, "to the degree that individuals reported acting prosocially, they also feel that their live are meaningful" (Van Tongeren et al. 2015, p. 8). Helping 
other people (spending money on others, volunteering) was related to a greater sense of purpose and meaning (Klein 2016). If we consider meaning in life as a part of well-being, we can argue using various research findings for the sake of relation between meaning in life and prosocial behaviour (e.g. prosocial costs lead to stronger improvements in happiness in situations that actually promote social connection, Aknin et al., 2013; prosocial behaviour can increase well-being without contact with beneficiary, Martela, Ryan, 2016).

In addition, researching prosocial behaviour is interesting for us to pursue a question of its relations to teacher interaction style. Ways how to engage pupils into process of learning are permanently in centre of educational research. Zepke and Leach (2010) in their meta-analysis of research identified ten most frequent ways how teacher encourages engagement of pupils, e.g. enable students to work autonomously, enjoy learning relationships with others and feel they are competent to achieve their own objectives; create learning that is active, collaborative and foster learning relationships; enable students to develop their social and cultural capital.

Above mentioned is connected with teacher interaction style - one of the factors encouraging the relations of pupil to learning and to school subject. Teacher interaction style is term used for labelling interpersonal teacher's behaviour in the class and interpersonal relationships between teacher and pupils, which are the result of teacher's behaviour. Research of teacher interaction style confirms that pupils are able via their evaluation to identify teachers-experts, who can involve pupils in the educational process; they understand pupils' needs; they are friendly; they can transfer responsibility to pupils and their extent of strictness is acceptable by pupils (Waldripp, Fisher 2003). The relations between teacher interaction style and pupils' school results have been sufficiently shown, on the other hand - the relation between teacher interaction style and pupils' values orientation or prosocial behaviour is investigated less.

\section{Backround}

\section{Prosociality and Prosocial Behaviour Development}

Prosocial behaviour is defined as voluntary action intended to benefit others (Batson 1998; Eisenberg et al. 2006) or behaviour involving costs for the self and resulting in benefits for others (Wittek, Bekkers, 2015). Acting is usually considered as prosocial under some conditions: it should benefit other people or groups; a person, who acts, acts voluntary, not under duty; an acting person acts without expecting reciprocity or reward (e.g. Zeldin, Small, Savin-Williams, 1984). Penner et al. (2005) describe micro-level (prosocial tendencies in humans and the etiology of individual differences in these tendencies), meso-level (behaviours of helper-recipient dyads 
within the context of a specific situation) and macro-level (prosocial actions within the context of groups and large organizations) of prosocial behaviour.

In our research, we were not interested in circumstances or motives of prosocial behaviour. The interest was rather focused on self-perceived prosocial behaviour how pupils assess themselves in performing prosocial acts within classroom and school, which usually express various types/forms of prosocial behaviour cooperation, helping, solidarity, cohesion, support. Our previous research affirmed that people subjectively assess their own prosocial behaviour considerably better than their colleagues, schoolmates, parents, siblings etc. (Brestovanský, 2014). In spite of this difference in assessment, the self-perceived prosocial behaviour express some kind of own orientation in acting and/or pursuit of some ways of performance. Wentzel et al. (2007) found that pursuit of prosocial goals by adolescents is an important mechanism that links prosocial actions to other psychological processes; pursuit of these goals was a direct predictor of prosocial behaviour and the remaining self-processes. The prosocial goals are also part of adolescents' personal projects and if they are meaningful, manageable and supported by others, they are associated with academic success, lower levels of risk behaviour and higher subjective well-being (Yeager, Bundick, 2009).

Other factors, which can correlate with prosocial behaviour, are teachers and school environment. Prosocial education can be considered as "an umbrella term that denotes all the various ways in which teachers develop effective classroom learning environments and teach the whole child, principals encourage positive school climates, superintendents assess the health and productivity of their systems, and communities and parents contribute to the well-being and thriving their children" (Brown \& d'Alessandro, 2012). It includes social and emotional learning (SEL), character education (CE), moral education, anti-bullying preventive programmes etc. There are hundreds of programmes of prosocial education worldwide, e.g. School Development Program (Comer, 1968); Positive Action (Allred 1977); Character Development Project (Ryan, Lickona 1992). Evaluation studies and meta-analyses of these programmes proved the effectiveness of character education based on prosocial education (Berkowitz, Bier 2005; Kanacri 2011). School and schooling is phenomenon connected with social and contextual processes related to changes in prosocial behaviour (Carlo et al. 1999).

At first, the school influence is considered as one of the important predictors of prosocial behaviour; if a school culture emphasizes cooperation and connectedness, it can facilitate positive peer relation and reduce emotional and behavioural problem (Brestovanský 2014; Lai - Siu, Shek 2015). Brugman et al. (2003) affirmed that the perception of moral atmosphere at school is a much better predictor of prosocial behaviour than is moral competence.

According to some researches, teacher-student relationship influences aggressive, defiant and prosocial behaviour. Obsuth et al. (2016) found out, that students perceiving a more positive relationship with their teacher at age 11 reported fewer 
aggressive behaviour and more prosocial behaviour. The same results affirmed measurements at ages 13 and 15. On the other hand, also students' teacher observed fewer aggressive and defiant behaviours and more prosocial behaviours.

If we consider prosocial behaviour within context of teacher interaction style, we want to express interpersonal behaviour of all subjects of interaction - pupils and teacher. Interpersonal behaviour is wider term as prosocial behaviour and some of interpersonal patterns of behaviour are just compatible with prosocial behaviour (e.g. affiliative behaviour, responsibility, cooperation).

\section{Meaning in Life}

The term 'meaning in life' is usually used as a term for explaining state of valuable and meaningful living. This phenomenon has been studied via various psychometric tools since the second half of $20^{\text {th }}$ century. This topic is frequently associated with existentialist analyses and logotherapy by V. E. Frankl, but following Halama (2007), the present concept is enriched by other approaches (existentialist, humanistic and cognitive). In contemporary research, the concept by Reker and Wong (1988, p. 221), who defined personal meaning as the "cognizance of order, coherence and purpose in one's existence, the pursuit and attainment of worthwhile goals, and an accompanying sense of fulfilment", is broadly used. They considered the meaning in life as a multidimensional construct containing three interconnected components: cognitive, motivational and affective.

Halama (ibid.) mentions a need of meaning of life in a sense of the need of aims. That means that the life meaning is a set of aims and tasks. This opinion is affirmed by some other authors, e.g. Debats (2000, in Halama, 2007) states that the main decisive factor in living life as meaningful is the level in which a person is able to follow his/her aims and ideals. Emmons (1999) states that the goals as such form a meaning in life. Without aims, it is not possible to realize how a person can experience his/her life as meaningful. Snyder and Feldman (2000) add that the person defines meaningful things in his/her life through aim-focused activities. In a meta-study, Auston and Vancouver (1996) mention more than 30 theories (including present theories) which pointed out aims in connection to meaning in life. We decided to use three-component model of meaning in life following the adaptation of this model in Slovak cultural environment. Halama (2007) considers this model as the most accepted and function approach to meaning in life. It can be assumed as the basis for reflection of this phenomenon and the way, how to define the term meaning in life.

We should mention, that the interest in research on prosociality and prosocial behaviour and their relation to meaning in life increased in last years (mainly in positive psychology). Some researchers affirmed the prosociality as one potential source of meaning and one way to procure it (Van Tongeren et al. 2015). However, there are hardly any researches directly focused on correlations between teenage/ 
adolescent prosocial behaviour and their meaning in life. Shek et al. (1994) used the Purpose in Life Test (C-PIL) in Chinese secondary school pupils. Results affirm significantly that the pupils with higher C-PIL scores show less antisocial behaviour and more prosocial behaviour; the data suggested that purpose in life is associated with positive social behaviour as indexed by prosocial behaviour. In our previous research, we found positive correlations between the data of the Test on Noo-dynamics and self-reported and peer-reported pupils' prosocial behaviour; as well positive correlation between positive noo-dynamics and interiorized and stereotyped prosocial moral reasoning (Brestovanský et al. 2016; Rajský, Podmanický 2016).

\section{Teacher Interaction Style}

Teacher interaction style describes teacher's interpersonal behaviour in the class. In previous research, the Questionnaire on Teacher Interaction (QTI, 1992) by Wubbel, Créton and Hooymayers was broadly used.

Mostly, the QTI was used in research on relationships between teacher interaction and student's attitude to school subjects. Fisher and Rickards (1998) found that the QTI scales is associated moderately strongly with student attitude scores and student attitude to Maths classes tended to be higher if teacher's behaviour was perceived as helping/friendly and leadership. On the other hand, student attitude was lower in the relation with perceived dissatisfied, admonishing and strict behaviours. These results are similar to the QTI use in Biology classes (Henderson at al. 1994, in Fisher et al. 1995) - a more favourable attitude towards the class and laboratory work was in classes where the students perceived leadership, understanding and helping/friendly behaviour in their teachers. Although some research with the QTI also indicated association of cognitive achievement or higher cognitive outcomes scores of students and helping, friendly and understanding teacher behaviour, e.g. Brekelmans, Wubbel and Levy (1993) found that higher cognitive outcomes scores in Physics were associated with helping, leadership and strict teacher behaviour. Scott and Fisher (2004) showed very similar results in research on teacher interaction and cognitive gains. Briefly, the more dominant is a teacher the better outcomes of his/her students are. As was mentioned, the research with the QTI is often aimed on student attitude to school subject and cognitive achievement in correlations with teacher behaviour.

Brekelmans et al. (1993) remind that the space in which teacher interaction style can influence student cognitive achievement is very limited and it is only one from many variables. We suppose that the extent of teacher influence is limited also by cultivating prosocial behaviour, moral reasoning and forming optimal class climate. In some research with the QTI focused on measurement of class climate or learning environment, the teacher leadership behaviour correlated with concord of school learning and home learning (Fisher, Waldrip 1999). Researching 
students' wellbeing, Van Petegem at al. (2007) found out that Language teachers who are viewed by students as dominant-cooperative appear to exert positive influence on student wellbeing. On the other hand, in the case of Mathematics teachers, their submissive-cooperative behaviours have a positive outcome on student wellbeing. Poulou (2014) affirmed that teacher's admonishing, uncertain and dissatisfied behaviour relate to students' inappropriate assertiveness, teachers' leadership and helping/friendly behaviour relates to students' appropriate social skills and teachers' uncertain behaviour relates to appropriate social skills in negative direction.

To sum up information about style of teachers' interaction in the classroom, teachers' interaction should be considered as one of many variables in educational process. However, significant influence of teachers' interaction on students' achievement, on attitudes to school subjects, on wellbeing, on imparting values and on some social skills, was observed in many findings.

\section{Research Design, Procedure and Methods}

This paper is based on simple quantitative research design, which is a part of wider research project of experimental evaluation of Ethics Education within prosociality context in Slovakia (see Rajský, Podmanický et al.2016). As we have not found any research precisely focused on correlations between self-perceived meaning in life and self-perceived prosocial behaviour as well as between self-perceived meaning in life and teacher interaction style, we decided to consider our contribution in this topic as a pilot study. Therefore, we aimed at two research questions: 1 . What correlation is between pupils' self-perceived meaning in life and self-perceived prosocial behaviour? 2. What correlation is between self-perceived meaning in life and teacher interaction style? To explain research findings, the results are divided in two independent results and interpretative parts that describe and explain main facts. The research design and analyses of data are based on descriptive and inductive statistics (e.g. simple comparative and correlative analysis).

We used a battery of several instruments, which are presented briefly in following text. To record teacher interaction style, we decided to use Slovak version of the QTI (SK-QTI) adapted and verified by Gavora et al. (2003). The SK-QTI is built on base of Leary's interpersonal concept describing a person in 16 basic interpersonal concept, which describes personality in 16 basic interpersonal dimensions - behavioural patterns. In our research, we used shorten version of SK-QTI (48 items) proved by Vašícková (2015). Mentioned items create eight interpersonal sectors, which are displayed graphically in circle diagram using Leary's interpersonal circumplex (1957). The SK-QTI (like another versions of QTI) describes and captures eight types of teacher interaction style - Leadership, Helping, Understanding, Responsible, Uncertain, Dissatisfied, Admonishing and Strict. 
The actual self-perceived meaning in life is the next variable used in our study. We used the Scale of Life Meaning (SLM) by Halama (2002) which is based on the concept by Reker and Wong (1988). This instrument consists of 20 items formulated as self-report and participants can express their dis/agreement using Likert-type scale (five-level items). Besides the total scores, partial sub-scales (cognitive, motivational and affective) can be evaluated. To show the content of SLM more concretely, we add some examples of its items: "I consider my life as valuable and useful."; "There are some things in my life, which I am involved in."; "I am looking forward to my life in future".

The last field, which we focus in our study on, is prosocial behaviour in school environment. In this case, we used the Questionnaire of Prosocial Behaviour (PROS by Roche, Sol 1998), which we revised and adapted in our previous research (Rajský, Podmanický 2016). We used PROS in self-form, it collects data about selfperceived prosocial behaviour of our participants. As Brestovanský (2016, in Rajský - Podmanický, 2016) mentions, content validity of PROS is based on classification of various manifestations of prosocial behaviour at school, who was created by Roche and Sol (1998). Parallel validity was proved by correlation of results of PROS particular forms with five selected items of SDQ questionnaire (Goodman 1997). Those items represent prosocial behaviour. To present the content of PROS, we can give some examples of its items: "I like helping others."; "I often encourage others." or "I willingly share with others."

\section{Participants}

Participants were involved in research by simple intentional sampling. The primary criterion was their age, respectively their attendance of the $8^{\text {th }}$ grade of lower secondary school. Data collection was anonymous and it was realized in one-off session with participants in February and March in 2017. Participants were asked to fill digital forms of questionnaires by trained co-worker. This procedure guaranteed $100 \%$ completing of research instruments.

The sample of pupils consisted of 429 Slovak lower secondary school pupils (female $45 \%, \mathrm{n}=195$ ) attending the eighth grade in 22 various schools in Slovakia. The majority of participants were 14 years old $(64 \%, n=276), 30 \%$ of pupils were 13 years old $(30 \%, n=128)$ and $6 \%$ of them were 15 years old $(n=25)$. By using the QTI, 22 teachers' $(\mathrm{n}=\mathbf{2 2})$ interactive style was evaluated by pupils in the sample.

Participation in our research was voluntary and none of the teachers or the pupils was paid for their participation. Parental consent was obtained and all data stored according to data protection regulations. 


\section{Research Results and Discussion}

\section{Meaning in Life and Self-Perceived Prosocial Behaviour}

Results of correlation analysis show that there is moderately strong positive correlation between self-perceived prosociality of pupils and meaning in life (Table 1). The level of pupils' self-perceived prosocial behaviour positively correlates with cognitive dimension $\left(r=, 40 ; r^{2}=, 16\right)$, motivational dimension $\left(r=, 37 ; r^{2}=, 14\right)$ as well as with affective dimension $\left(r=, 35 ; r^{2}=, 12\right)$ of meaning in life. In the case of effect of proven relations, it is shown, that relation between self-perceived pupils' prosocial behaviour and cognitive dimension of meaning in life explains $16 \%$ of total variance. The similar effect is observed also in prosocial behaviour and motivation dimension (14\%) and affective dimension (12\%) of pupils' meaning in life; following Tolson (1980), we can consider it as significant part.

Table 1 Correlation analysis of meaning in life and prosocial behaviour of pupils

\begin{tabular}{|c|c|c|c|}
\hline & \multicolumn{3}{|c|}{ Prosocial behaviour } \\
\hline & $\mathbf{r}$ & $\mathbf{r}^{2}$ & $\mathbf{p}$ \\
\hline Cognitive dimension &, 40 & , 16 &, $00^{* * *}$ \\
\hline Motivational dimension &, 37 & 14 &, $00^{* * *}$ \\
\hline Affective dimension & ,35 & 12 &, $00^{* * *}$ \\
\hline
\end{tabular}

$\mathrm{n}=429 ; r$ - Pearsons correlation coeffiecient; $r^{2}$-effect size coefficient of determination; $p$ - significance value;

Results show that self-perceived prosocial behaviour is in positive relation with self-perceived meaning in life. As we mentioned, similar results are affirmed in some present research (Van Tongeren et al. 2015), in which the positive relation between self-reported prosocial behaviour and meaning in life is evident. Our research cannot unambiguously show, if prosocial behaviour improves meaning in life or vice versa. Research by Klein (2016) supports positive influence of realized prosocial behaviour on perceived meaning in life, in other words - real prosocial performance (helping, volunteering) raises perceived meaning in life. Similarly, the positive correlations between results of the Test on Noo-dynamics and pupils' self-perceived prosocial behaviour was found in our previous research (Rajský, Podmanický 2016).

If we mention the relation between self-perceived prosocial behaviour and meaning in life, we consider prosociality as a certain value - a possible source of 
meaning in life. This is supported in series of research by Ebersole (1998) realized with various age groups (children and students, adults, marriage couples, volunteers in non-profit organizations etc.). According to results of research, Ebersole (1998) identified eight types of meaning in life especially the first two of them (relations and services) are defined similarly as prosocial orientation.

Dimension of relationships as the source of meaning in life is presented in connection to interpersonal orientation of person, which embraces family, friends, partnership and all significant relation persons. The second source is service, which is mainly considered as help and support of others, but it is not specified, if the service is prosocial, respectively non-profit. Orientation on relationships and service can give motivation long-termly and make possible meaning in life of person. In our case, this interpretation increases its importance, if we add the fact that interpersonal orientation on relationships and shift from egocentrism to perception of others and relating to others have importance in the ontogenesis, especially in adolescence period.

\section{Teacher Interaction Style and Pupils' Self-Perceived Prosocial Behaviour}

Results in our second study predicts, that statistically significant correlations exist between perceived interaction styles of teacher and self-perceived prosociality of pupils (Table 2). Moderately strong positive correlations are found between pupils' prosocial behaviour and leadership style $\left(r=, 36 ; r^{2}=, 13\right)$, helping style $\left(r=, 36 ; r^{2}=, 13\right)$, understanding style $\left(\mathrm{r}=, 33 ; \mathrm{r}^{2}=, 11\right)$ and responsible interaction style $\left(\mathrm{r}=, 33 ; \mathrm{r}^{2}=, 11\right)$.

Concerning effects of shown correlations, all mentioned 'prosocial' styles of teacher interaction explain more than $10 \%$ of total variance of pupils' prosocial behaviour. Only weak negative correlations are found between remaining four interactive teacher styles (uncertain, dissatisfied, admonishing and strict) and self-perceived pupils' prosocial behaviour. Weak negative correlations imply, that prosocial behaviour can link, in some extent, with 'anti-prosocial' teacher interaction style, which could be disserviceable for development of pupils' prosociality. Coefficient of determination correlating prosocial behaviour and uncertain, dissatisfied, admonishing and strict interaction style of teacher was lower than $0,1\left(\mathrm{r}^{2} \leq, 10\right)$; it implies lower than $10 \%$ part in total variation. 
Table 2 Correlation analysis of teacher interpersonal behaviour and pupils' self-perceived prosocial behaviour

\begin{tabular}{|c|c|c|c|}
\hline \multicolumn{4}{|c|}{ Prosocial behaviour } \\
\hline & $\mathbf{r}$ & $\mathbf{r} 2$ & $\mathbf{P}$ \\
\hline Leadership &, 36 & 13, &, $00^{\star * *}$ \\
\hline Helping &, 36 & ,13 &, $00^{* * *}$ \\
\hline Understanding &, 33 & ,11 &, $00^{\star * *}$ \\
\hline Responsible & 33 &, 11 &, $00^{\star * *}$ \\
\hline Uncertain &,- 20 & ,04 &, $00^{* * *}$ \\
\hline Dissatisfied &,- 28 & , o8 &, $00^{* * *}$ \\
\hline Admonishing &,- 22 &, 05 &, $00^{\star * *}$ \\
\hline Strict &,- 12 & ,01 &, $01^{* *}$ \\
\hline
\end{tabular}

$\mathrm{n}=429 ; r$ - Pearsons correlation coefficient; $r 2$-effect size coefficient of determination; $p$ - significance value;

Our first analysis shows existing relation between particular types of teacher interaction style and self-perceived prosocial behaviour of pupils. Interaction style is considered as relatively stable characteristics of teacher (Gavora et al. 2003), which represents his/her interpersonal performance in class. Particular interactions, which happen between pupils and teacher during educational process, are gradually steady and form interpersonal patterns of behaviour - teacher interaction style.

Various authors (e.g. Wubbels, Levy 1991; den Brok 2001; Gavora et al. 2003) agree that interaction style reciprocally affects interpersonal behaviour of pupils, school/classroom climate, motivation, mood and many other variables existing in pupils and class as small social group. It seems to be, that types of interaction style, which have usually relations to school subject or school results (Brekelmans et al. 1993; Scott, Fisher 1994), have relation also to prosocial behaviour of pupils.

Partial research affirms, that interaction style of teacher affects not only cognitive performance of pupils but also their social and emotional skills, respectively absence of emotional problems or behavioural problems (Polou 2014), moral norms and values (Sivan, Chan 2013), pupils' wellbeing (Van Petegem et al. 2007) and perception of pupils' subjective wellbeing (Köverová 2015). Simultaneous, interpersonal circle diagram, originally by Leary (2017), later modified by others (e.g. Wiggins 1995; Lorr 1996; Gavora et al. 2003), displays particular teacher interaction styles arranged and express their mutual relation of particular dimensions. We should mention that complementary teacher and pupils' reactions or symmetric reaction to manifestation of interactive style could occur. If teacher is friendly, helping and understanding, it can bring affiliative, friendly, responsible and organization pupils' behaviour. Watzlawick et al. (1999) pointed the principle of symmetry out. 
Dominant and strict teacher can often cause by his/her behaviour reactions as subordination, submissive cooperation etc.

We assume, if a teacher is perceived as helping, it means, that s/he is able to react on pupils' needs sensitively and is ready to help them. S/he is friendly, forms and supports pleasant and safe climate in the class and pupils can trust her/him. It is presumable, that $\mathrm{s} / \mathrm{he}$ is quite understanding, patient and tolerant, able to listen to pupils' opinions and discuss with them. At the same time, s/he can have leadership interaction style and it means that $\mathrm{s} /$ he have good knowledge about everything what happens in class. S/he leads education process effectively, can make interested pupils in topic and hook their attention, explains topic comprehensibly.

According to mentioned, correlations in our research are logical and expected. We supposed, that exactly behaviour of understanding, helping teacher, who leads to responsibility, is similar to prosocial behaviour is such way how Roche Olivar (1992) describes it. Roche Olivar (1992) categorizes some types of prosocial behaviour, e.g. physical help, physical service, sharing, verbal help and support. Understanding, friendly and helping teacher, who is able to be empathetic to pupils, to accept them without conditions, to support their own decision and take responsibility for it, becomes congruent prosocial model.

\section{Conclusion}

Our paper is focused on correlations between pupils' self-perceived prosocial behaviour and meaning in life and likewise on teacher interaction style and self-perceived meaning in life of fourteen-year-old and fifteen-year-old pupils.

In the first study, positive correlation were proved between self-perceived prosociality and cognitive, motivational and affective dimensions of pupils' meaning in life. This means, that pupils' who consider their life as meaningful have tendency to perceived themselves as more prosocial and vice versa. But our findings cannot show, if meaning in life improves self-perception of prosocial behaviour or contrariwise.

In the second study, it was shown that a teacher could improve self-perceived prosocial behaviour of pupils if $s /$ he is evaluated with higher score in dimensions of leadership, understanding and responsibility. In contrary, dimensions of teacher interaction style as strict, uncertain, dissatisfied and admonishing correlate negatively with self-perceived prosocial behaviour of pupils.

Our findings are similar to numerous findings of various authors (e.g. Wubbels, Levy, 1993; den Brok, 2001; Gavora, Mareš, den Brok, 2003; Rajský, Podmanický, 2014, 2016). Rajský and Podmanický (2014) emphasize that the person, who wants to lead and educate others, has to dispose of inexhaustible humanity raising from functioning prosocial relationships. They affirm that one of dominant factors, which influences effectiveness of educational process, is a teacher personality (in our consideration interpersonal adjustment of teacher - interaction style). Wubbels 
and Levy (1993) confirm positive correlation of affective results of education to teacher interaction style in some dimensions (Leadership, Helping, Understanding, Responsible), which is supported also by our results.

For sure, the quantitative design of research bears some risk and limitations in analysed variables and correlations between teacher interaction style, prosocial behaviour and pupils' meaning in life. After rethinking our research design, we found out that it would be useful to re-evaluate its form and choice of instruments battery. Despite appropriate psychometric parameters of our instruments, their triangulation could offer more objective look into explored variables. Triangulation could be used in teacher interaction style measurement, but we noticed only pupils' opinion on teacher interaction style, his/her own self-perception is missing. It would be useful for objectivity of findings. On the other hand, we are aware of difficulty of measurement of meaning in life in this age. The methods of multi-variation statistics and statistics modelling may be used in analysis of results.

\section{Acknowledgments}

This work was supported by Ministry of Education, Science and Sport of Slovak Republic, via project VEGA 1/0557/16 Verification of Basic Orientation on Prosociality Concept in Ethics Education.

\section{References}

Aknin L. B., Dunn E. W., Sandstrom G. M., Norton M. I. (2013). Does social connection turn good deeds into good feelings? On the value of putting the "social" in prosocial spending. "International Journal of Happiness and Development", Vol. 1, No. 2, pp. 155-171.

Batson C. D. (1998). Altruism and prosocial behavior. In: Gilbert D., Fiske S., Lindzey, G. (ed.). The handbook of social psychology. New York: McGraw-Hill.

Berkowitz M. W., Bier M. C. (2005). What Works In Character Education: A research-driven guide for educators. Missouri: CEP.

Brekelmans M., Wubbels T., Levy J. (1993). Student Performance, Attitudes, Instructional Strategies and Teacher-Communication Style. In: Wubbels T., Levy J. (ed.). Do You Know What You Look Like? Interpersonal Relationships in Education. London: Falmer Press. Taylor and Francis.

Brestovanský M. (2014). Metodologické otázky výskumu prosociálnosti. In: Podmanický I., Rajský A. (ed.). Prosociálnost a etická výchova. Skúsenosti a perspektívy. Trnava: Typi Universitatis Tyrnaviensis.

Brestovanský M. et al. (2016). Noodynamics positively influences prosocial behaviour. In: SGEM Conference Proceedings. Bulgaria: STEF92 Technology Ltd., pp. 675-682. 
Brown P.M., Corrigan M.W., D’Alessandro A. (ed.) (2012). The Handbook of Prosocial Education. Lanham, MD: Rowman \& Littlefield.

Brugman D. et al. (2003) Perception of moral atmosphere in school and norm transgressive behaviour in adolescents. An intervention study. "International Journal of Behavioural Development", Vol. 27, No. 4, pp. 289-300.

Carlo G., Fabes, R. A. Laible, D. Kupanoff K. (1999). Early Adolescence and Prosocial/ Moral Behavior II: The Role of Social and Contextual Influences. "Journal of Early Adolescence", Vol. 19, No. 2, pp. 133-147. Available at: http://digitalcommons.unl. edu/psychfacpub/44 (Retrieved 25.01.2018).

Comer J. P. (1968). Comer School Development Program, available at http://medicine. yale.edu/childstudy/comer/ (retrieved: 11.30.2017).

Den Brok P. (2001). Teaching and student outcomes. A study of teacher's thoughts and action from an interpersonal and a learning activities perspective. Utrecht: W.C.C.

Ebersole P. (1998). Types and depth of written life meaning. In: Wong P. T. P., Fry P. M. (ed.). The human quest for meaning. A handbook of psychological research and clinical applications. Mahwah - London: Lawrance Erlbaum Associates.

Eisenberg, N., Fabes, R. A. (1998). Prosocial development. In: Eisenberg N., Damon W. (ed.) Handbook of child psychology: Vol. 3. Social, emotional, and personality development. New York : Wiley.

Emmons R. A. (1999) Psychology of ultimate concerns. New York: Guilford Press.

Flay B. R., Allred C. G. (2010). The Positive Action Program: Improving Academics, Behaviour, and Character by Teaching Comprehensive Skills for Successful Learning and Living. In: Lovat T. et al. (ed.) International Research Handbook on Values Education and Student Wellbeing. DOI 10.1007/978-90-481-8675-4_28

Fisher D., Fraser B., Cresswell J. (1995). Using the "Questionnaire on Teacher Interaction" in the Professional Development of Teachers. "Australian Journal of Teacher Education“, Vol. 20, No. 1. Available at: http://dx.doi.org/10.14221/ ajte.1995V2on1.2 (retrieved: 11.20.2017)

Fisher D., Rickards T. (1998). Associations between Teacher-Student Interpersonal Behaviour and Student Attitude to Mathematics. "Mathematics Education Research Journal“, Vol. 10, No. 1, pp. 3-15.

Fisher D. L., Waldrip B. G. (1999). Cultural Factors of Science Classroom Learning Environments, Teacher-Student Interactions and Students Outcomes. "Research in Science and Technological Education“, Vol. 17, No. 1, pp. 83-96.

Fry P. M. (1998). The development of personal meaning and wisdom in adolescence: A reexamination of moderating and consolidating factors and influences. In: Wong, P. T. P., Fry P. M. (ed.). The human quest for meaning. A handbook of psychological research and clinical applications. Mahwah - London: Lawrance Erlbaum Associates.

Gavora P., Mareš J., den Brok P. (2003). Adaptácia Dotazníka interakčného štýlu učitela. "Pedagogická revue“, Vol. 55, No. 2, pp. 126-145. 
Goodman R. (1997). The Strengths and Difficulties Questionnaire: A Research Note. "Journal of Child Psychology and Psychiatry", Vol. 38, No. 5, pp. 581-586.

Halama P. (2002). Vývin a konštrukcia škály životnej zmysluplnosti. “Československá psychologie“, Vol. 46, No. 3, pp. 265-276.

Halama P. (2007). Zmysel života z pohladu psychológie. Bratislava: Slovak Academic Press.

Kanacri B. P. L. (2011). Development and Promotion of Prosocial Behavior from Adolescence to Young Adulthood: Antecedents and Civic Outcomes. Dissertation Thesis. Rome: Sapienza Universitá di Roma.

Klein N. (2016). Prosocial behavior increases perceptions of meaning in life. "The Journal of Positive Psychology", available at http://www.tandfonline.com/ doi/full/10.1080/17439760.2016.1209541 (retrieved: 07.31.2017).

Köverová M. (2015). Percepcia interakčného štýlu učitela a subjektívna pohoda študentov. "Psychologie a její kontexty", Vol. 6, No. 1, pp. 33-48.

Lai F. H. Y., Siu A. M. H., Shek D. T. L. (2015). Individual and social predictors of prosocial behavior among Chinese adolescents in Hong Kong. "Frontiers in Pediatrics“, Vol. 3, No. 39, pp. 1-8. Doi: 10.3389/fped.2015.00039

Leary T. (1957). An Interpersonal Diagnosis of Personality. New York: Ronald Press. Lorr M. (1996). The Interpersonal Circle as a Heuristic Model for Interpersonal Research. "Journal of Personality Assessment", Vol. 66, No. 2, pp. 234-239.

Mareš J., Gavora P. (2004). Interpersonální styl učitelü: teorie, diagnostika a výsledky výzkumi. "Pedagogika", Vol. LIV, pp. 101-128.

Martela F. - Ryan R. M. (2016) Prosocial behaviour increases well-being and vitality even without contact with the beneficiary: Causal and behavioral evidence. "Motivation and Emotion", Vol. 40, Issue 3, pp. 351-357.

Obsuth I., Murray A. L., Malti T., Sulger P., Ribeaud D., Eisner M. (2017). A Non-bipartite Propensity Score Analysis of the Effects of Teacher-Student Relationships on Adolescent Problem and Prosocial Behavior. "Journal of Youth and Adolescence", Vol. 46, No. 8, pp. 1661-1687. DOI 10.1007/s10964-016-0534-y

Penner L. et al. (2005). Prosocial Behavior: Multilevel Perspectives. "Annual Review Psychology", 2005, pp. 366-385.

Polou M. S. (2014). Teacher-student relationships, social and emotional skills, and emotional and behavioural difficulties. "Educational Journal of the University Patras UNESCO Chair”, Vol. 1, No. 1, pp. 34-47.

Rajský A., Podmanický I. (ed.) (2014). Prosociálnost'a etická výchova. Skúsenosti a perspektívy. Trnava: TYPI UNIVERSITATIS TYRNAVIENSIS.

Rajský A., Podmanický I. (ed.) (2016). Človek človeku. K prameňom etickej výchovy. Trnava: VEDA.

Reker G. T., Peacock E. J. Wong, P. T. P. (1987). Meaning and Purpose in Life and Well-Being: A Life-Span Perspective. "Journal of Gerontology", Vol. 42, No. 1, pp. 44-49. 
Reker G. T., Wong P. T. P. (1988). Aging as an individual process: Toward a theory of personal meaning. In: Birren J. E., Bengston V. L. (ed.) Emergent theories of aging. New York: Springer, 1988.

Roche R. O., Sol, N. (1998). Educación prosocial de las Emociones, Valores y Actitudes positivas. Barcelona: Blume.

Ryan K., Lickona T. (ed.) (1992). Character Development in schools and beyond. 2. ed. Washington, DC: The Council for Research in Values and Philosophy.

Scott R. H., Fisher D. L. (2004). Development, Validation and Application of a Malay Translation of an Elementary Version of the Questionnaire on Teacher Interaction. "Research in Science Education", No. 34, pp. 173-194.

Shek D. T. L., Ma H. K., Cheung P. C. (1994). Meaning in life and adolescent antisocial and prosocial behavior in a Chinese context. "Psychologia: An International Journal of Psychology in the Orient", Vol. 37, No. 4, pp. 211-218.

Snyder C. R., Feldman D. B. (200o) Hope for the many: An empowering social agenda. In Snyder C. R. (ed.) Handbook of hope. Theory, measures and applications. San Diego - London: Academic Press, pp. 389-412.

Tolson H. (1980). An adjunct to statistical significance: $\omega 2$. "Research Quarterly for Exercise and Sport", Vol. 51, No. 3, pp. 580-584.

Vašičková S. (2015). Správa z merania interakčného štýlu učitela. Výskum sprievodných aspektov vzdelávania. Bratislava: NÚCEM. Available at: http://www.etest.sk/ data/att/599.pdf (retrieved: 1.21. 2017)

Van Petegem K., Aelterman A., Van Keer H., Rosseel Y. (2008). The influence of student characteristics and interpersonal teacher behaviour in the classroom on student's wellbeing. "Social Indicators Research", Vol. 85, No. 2, pp. 279-291. DOI 10.1007/s11205-007-9093-7.

Van Tongeren D. R., Green J. D. Davis, D. E. Hook, J. N. Hulsey T. L. (2015). Prosociality enhances meaning in life. "The Journal of Positive Psychology", Vol. 10, No. 3, pp. 1-12. Available at: https://www.researchgate.net/publication/277950335_Prosociality_enhances_meaning_in_life(retrieved: 9.20. 2017)

Waldripp B. G., Fisher D. L. (2003). Identifying exemplary science teachers through their classroom interactions with students. "Learning Environments Research", Vol. 6, pp. 157-174.

Watzlawick P., Bevelasová J. B. Jackson, D. D. (1999). Pragmatika lidské komunikace. Hradec Králové: Konfrontace.

Wentzel K. R., Fillisetti L., Looney, L. (2007). Adolescent Prosocial Behavior: The Role of Self-Processes and Contextural Cues. "Child Development", Vol. 78., No. 3, pp. 895-910.

Wiggins J. S. (1995). Interpersonal Adjective Scales: Professional Manual. FL: Odessa, Psychological Assessment Resource.

Wittek R., Bekkers R. (2015). Altruism and Prosocial Behavior, Sociology of. In Wright, J. D. (ed.) (2015). International Encyclopedia of the Social $₫$ Behavioral Sciences. Oxford: Elsevier. Vol 1. pp. 579-583. 
Wubbels T., Creton H. A., Hooymayers H. P. (1992). Review of research on teacher communication styles with use of the Leary model. "Journal of Classroom Interaction", Vol. 27, pp. 1-12.

Wubbels T., Levy J. (1991). A comparison of interpersonal behaviour of Dutch and American teachers. "International Journal of Intercultural Relations", Vol. 15, pp. $1-18$.

Wubbels T., Levy J. (1993). Do you know what you look like? London: The Falmer Press.

Yeager D. S., Bundick M. J. (2009). The Role of Purposeful Work Goals in Promoting Meaning in Life and in Schoolwork during Adolescence. "Journal of Adolescent Research", Vol. 24, No. 4, pp. 423-452.

Zeldin R. S., Savin-Williams R. C. Small S. A. (1984). Dimensions of prosocial behavior in adolescent males. "The Journal of Social Psychology", Vol. 123, No. 2, pp. 159-168.

Zepke N., Leach L. (2010). Improving student engagement: Ten proposals for action. "Active Learning in Higher Education", Vol. 11, No. 3, pp. 167-177.

\section{PROSPOŁECZNOŚĆ UCZNIÓW I JEJ ZWIĄZKI Z SENSEM ŻYCIA I INTERAKTYWNYM STYLEM PRACY NAUCZYCIELA}

Streszczenie: Badanie dotyczy samopostrzegania zachowań prospołecznych przez uczniów oraz ich związku z postrzeganiem sensu życia i stylem interakcji stosowanym przez nauczyciela. Respondentami byli uczniowie ze szkoły ponadpodstawowej w wieku 13-15 lat. Celem badania było ustalenie, jaki jest związek między samopostrzeganiem zachowań prospołecznych przez uczniów a stylem interakcji nauczyciela. Jednocześnie dokonano analizy związku między postrzeganiem swoich zachowań prospołecznych przez uczniów a sensem życia. Okazało się, że nauczyciele i ich styl interakcji może pozytywnie wpływać na samopostrzeganie zachowań prospołecznych u uczniów, pod warunkiem że dany nauczyciel jest oceniany wysoko pod względem swoich umiejętności przywódczych oraz jako osoba wyrozumiała i odpowiedzialna. Korelacja negatywna zachodzi, gdy interakcję nauczyciela z uczniami cechuje surowość, niepewność, niezadowolenie oraz stosowanie kar.

Słowa kluczowe: styl interakcji nauczyciela, sens życia, zachowanie prospołeczne.

Anna Sádovská - PhD, her interests are focused on methodology of Ethical Education, Moral Education, educational counselling and multicultural education in her research and educational activities. She also researches prosocial behaviour and moral reasoning of pupils, field of perception of cultural diversity by pupils and inclusion of pupils in mainstream schools. As a member of Central Committee for Ethical Education she has taken part in improving of educational content of Ethical Education. E-mail-Address: anna.sadovska@gmail.com. 
Peter Kusý - PhD, his interests are focused on methodology of educational and psychological research, topics from music therapy and music psychology, topics of foster care. He has been a chief-redactor of E-mental: electronic journal about mental health, which is published by support of Slovak Association of Students and Absolvents of Psychology - SAŠAP. The most important publications: Using of Music Therapy in Integrative Psychotherapy in the journal Arteterapie (2014), papers Interpersonal behaviour and music preferences of older school age children (2015); Prosocial behaviour and prosocial orientation on 11-12-years-old pupils in Slovakia (2014): Education and educational research (2015). E-mail-address: peterkusy7@gmail.com. 